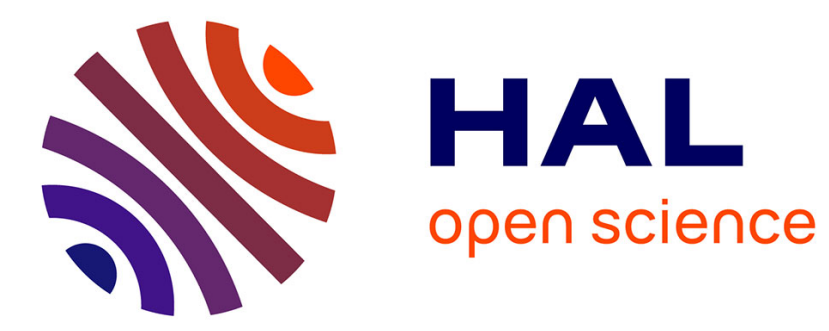

\title{
Stability of some centres in quartz
}

Christophe Falguères, Yuji Yokoyama, Didier Miallier

\section{To cite this version:}

Christophe Falguères, Yuji Yokoyama, Didier Miallier. Stability of some centres in quartz. Nuclear Tracks and Radiation Measurements, 1991, 18 (1/2), pp.155-161. halshs-00406599

\section{HAL Id: halshs-00406599 \\ https://shs.hal.science/halshs-00406599}

Submitted on 23 Jul 2009

HAL is a multi-disciplinary open access archive for the deposit and dissemination of scientific research documents, whether they are published or not. The documents may come from teaching and research institutions in France or abroad, or from public or private research centers.
L'archive ouverte pluridisciplinaire HAL, est destinée au dépôt et à la diffusion de documents scientifiques de niveau recherche, publiés ou non, émanant des établissements d'enseignement et de recherche français ou étrangers, des laboratoires publics ou privés. 


\title{
STABILITY OF SOME CENTRES IN QUARTZ
}

\author{
C. FalguÈres, ${ }^{*}$ Y. Yokoyama* and D. Miallier $\dagger$ \\ *Institut de Paléontologie Humaine, URA 184 du CNRS, 1, rue R. Panhard, 75013 Paris, France and \\ $\nmid$ Laboratoire de Physique Corpusculaire, F63177 Aubière Cedex, France
}

\begin{abstract}
Electron spin resonance (ESR) is a promising dating method for Quaternary sediments. A preliminary ESR analysis was done on quartz grains extracted from sediments baked by lava-flows of Massif Central (France). For this type of sample, zeroing occurs during heating. To test the reliability of the method, the palaeodoses were determined from centres (All and $\mathrm{Ti}$ ) and compared with those obtained by the thermoluminescence (TL) method.

The annealing temperature and sunlight have an effect upon the stability and the behaviour of the different ESR signals. An attempt to correlate ESR signals and the red TL peak is made in terms of the variation of these two factors.
\end{abstract}

\section{INTRODUCTION}

QUARTZ is a mineral with a stable structure which is well defined, so, we can use the electron spin resonance (ESR) method. ESR lines are generally narrow, allowing accurate measurements of $g$ values. The main centres known in quartz are aluminium, titanium, germanium, $E^{\prime}$ and oxygen centres.

Our quartz samples were extracted from sediments baked by lava-flow which originated from the Tartaret volcano at Neschers (Massif Central, Chaîne des Puys, France) and are called C94. For these samples, zeroing was made by heating, and hence there is no problem. Previous studies have been carried out, particularly on $\mathrm{Al}$ and $\mathrm{Ti}$ centres (Yokoyama et al., 1985a).

- Thermoluminescence (TL) studies have also been done on the C94 samples (Sanzelle et al., 1984).

In the present work, we searched for possible correlation between TL peaks (and especially the red peak at $380^{\circ} \mathrm{C}$, which is the best-behaved) and ESR signals. In order to perform these experiments, light exposure and thermal annealing were used.

\section{EXPERIMENTAL}

The C94 samples were collected by D. Miallier. Locally, the lava-flow thickness is around $6-8 \mathrm{~m}$ and the sample was extracted from about $10 \mathrm{~cm}$ below the sediment-lava interface. So it was expected that the sediment was originally annealed around $800^{\circ} \mathrm{C}$, with a very slow cooling rate. The method used for the sample preparation was that used by TL investigators, and was done under subdued light. This procedure has been described previously (Yokoyama et al., 1985a, b ). Then, in order to protect the samples from light exposure, they were enclosed in light-tight bags.

Aliquots of about $300 \mathrm{mg}$ of $100-200 \mu \mathrm{m}$ separated quartz were irradiated with a ${ }^{137} \mathrm{Cs}$ gamma source (delivering $3.810^{-2} \mathrm{~Gy} \mathrm{~s}^{-1}$ ). Afterwards, the samples were split into two series, one for TL and the other for ESR studies.

The measurements were carried out with an ESR spectrometer Varian E109 with a microwave frequency of $9 \mathrm{GHz}$ (X band). The hyperfine structure of signals $\mathrm{Al}$ and $\mathrm{Ti}$ may be disturbed if there is too much dipolar magnetic interaction created by the vicinity of nuclear spins. These conditions can be decreased by working at a low cavity temperature. In addition, $\mathrm{Al}$ and $\mathrm{Ti}$ centres are not superposed, which allows for a comparative study. The ESR thermal annealing treatments were done in an automatic regulating furnace $\left( \pm 1^{\circ} \mathrm{C}\right.$ of accuracy).

For TL studies, experiments were made at a heating rate of $5^{\circ} \mathrm{C} \mathrm{s}^{-1}$ in flowing nitrogen. The $\mathrm{TL}$ equipment was built in the Clermont laboratory, using Georges Valladas plans as concerns hardware (unpublished). The PM tube was a bi-alkali EMI 9635 QA.

\section{ESR CENTRES}

\section{$\mathrm{E}^{\prime}$ centre}

This is one of the most studied centres in quartz. It has been well characterized in alpha quartz and silica glass (Griscom, 1978). Its $g$-value is 2.0005 . The intensity of the $E^{\prime}$ centre of quartz extracted from quaternary sediments often decreases after ${ }^{60} \mathrm{Co}$ gamma-ray irradiations, in regard to that of natural samples. This indicates that the $E^{\prime}$ centre is already saturated in these non-irradiated samples (Yokoyama et al., 1985b). We did not see the $E^{\prime}$ centre in our Neschers samples. 


\section{Oxygen centre}

The oxygen-associated hole centres are not well characterized in alpha quartz. Two types of $\mathrm{OH}$ centres have been proposed in silica glass (Stapelbroek and Griscom, 1978). One of them has been found in igneous, sedimentary and metamorphic quartz. McMorris (1970) attributed this signal to centres in amorphous, glass-like regions of structural damage created by nuclei recoiling in alpha-emission, and he called this centre the radiation damage centre. It was later found to be a peroxyradical (Griscom and Friebele, 1981). We did not observe this damage centre in our C94 samples.

In Fig. 1, we can observe an "unidentified" signal at $g=2.01$, which is close to the $g$-value of the non-bonding oxygen hole centre $\left(g_{2}=2.0095\right)$. The intensity of this signal is very small in the most irradiated sample. The growth curve was determined only to study the thermal stability of this centre.

\section{Germanium centre}

This type of centre is well known in alpha quartz and many studies carried out on germanium ions substitutional at $\mathrm{Si}$ sites. Its $g$-value is 1.996 . Weil (1984) described the structure of this centre.

For our samples, this signal becomes detectable only after gamma-ray irradiations. The same phenomenon was observed for two palaeolithic sunlight bleached sediments (Yokoyama et al., 1985b). McMorris (1971) also reported the absence of $\mathrm{Ge}$ signal in his natural samples. He explained it by the natural optical bleaching or by the natural change of the alkali ion states associated with the Ge centre. For our samples, the possibility of a natural optical bleaching may be excluded. Therefore, the second explanation of McMorris may be suitable. On the other hand, Shimokawa et al. (1984) used the Ge centre signal for the ESR dating of quartz in a volcanic rock. The Ge centre was also observed in natural quartz extracted from mylonite (Fukuchi, 1988). Therefore, the vanishing (or the persistence) of the Ge centre signal depends on the nature of rock, and cannot be generalized. Figure 1 shows a Ge centre signal in one of our irradiated samples.

\section{Titanium centre}

Some electron traps exist in natural quartz and are attributed to substitutional Ti (Weil, 1984). In addition to hyperfine structure ( $h f s$ ) due to major $\mathrm{Ti}$ isotopes, the signal exhibits alkali superhyperfine structure $(s h f s)$. The Ti centre has three main components at $g=1.910, g=1.930$ and $g=1.980$. The signal height is measured from the top alkali $s h f s$ $(g=1.930)$ to the bottom of it, as indicated by the arrows (Fig. 2).

\section{Aluminium centre}

The $\mathrm{Al}$ centre is a hole centre. In quartz there is a substitution of $\mathrm{Si}$ by $\mathrm{Al}$ plus one interstitial cation which maintains charge neutrality (Weil, 1984). The Al centre is characterized by a $h f s$. This centre has

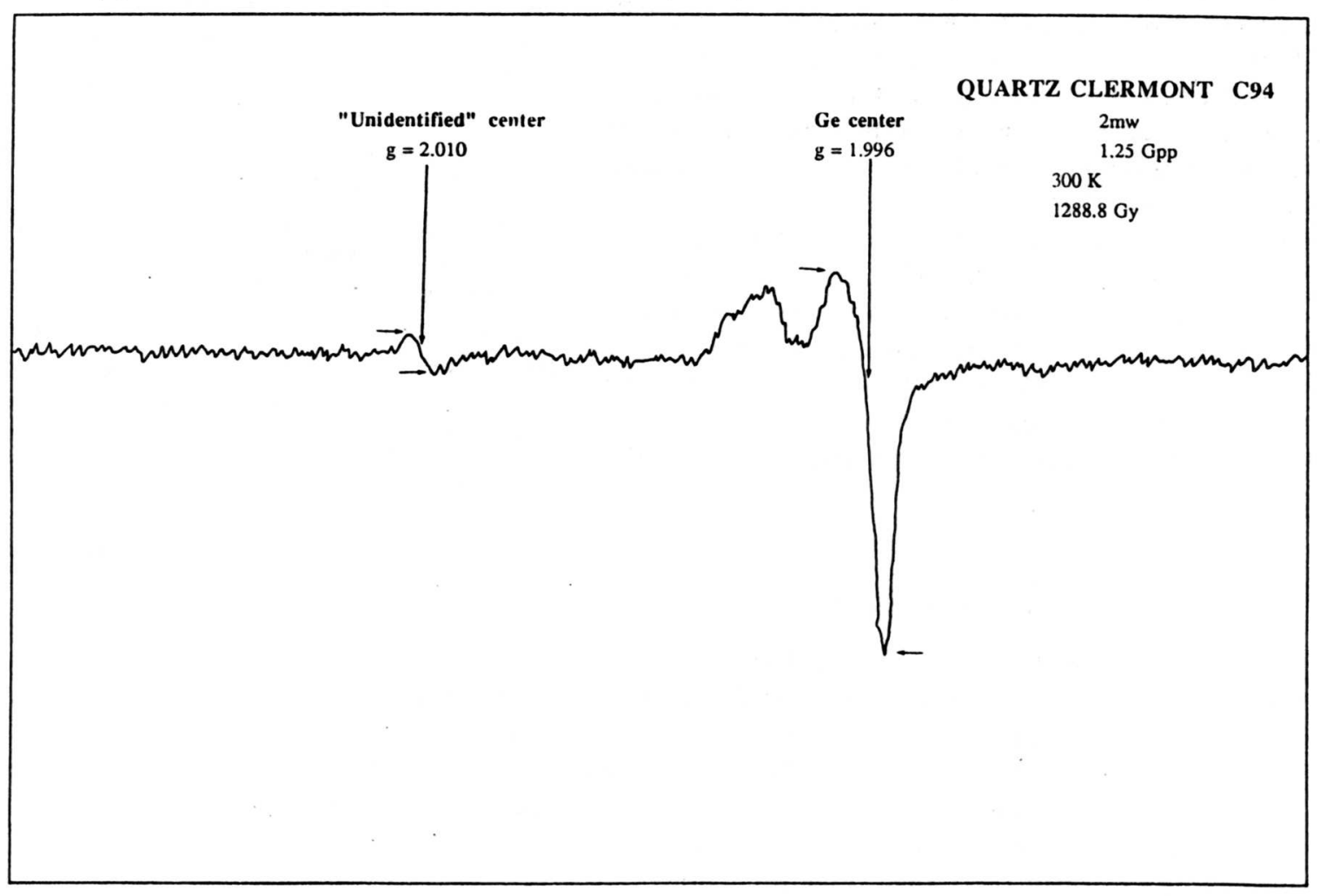

FIG. 1. ESR spectrum of $\mathrm{OH}$ and Ge centres of an irradiated quartz sample (C94). These centres are observed at a cavity temperature of $293 \mathrm{~K}$. A microwave power of $2 \mathrm{~mW}$ is used. The arrows indicate how the signals' heights are measured. 


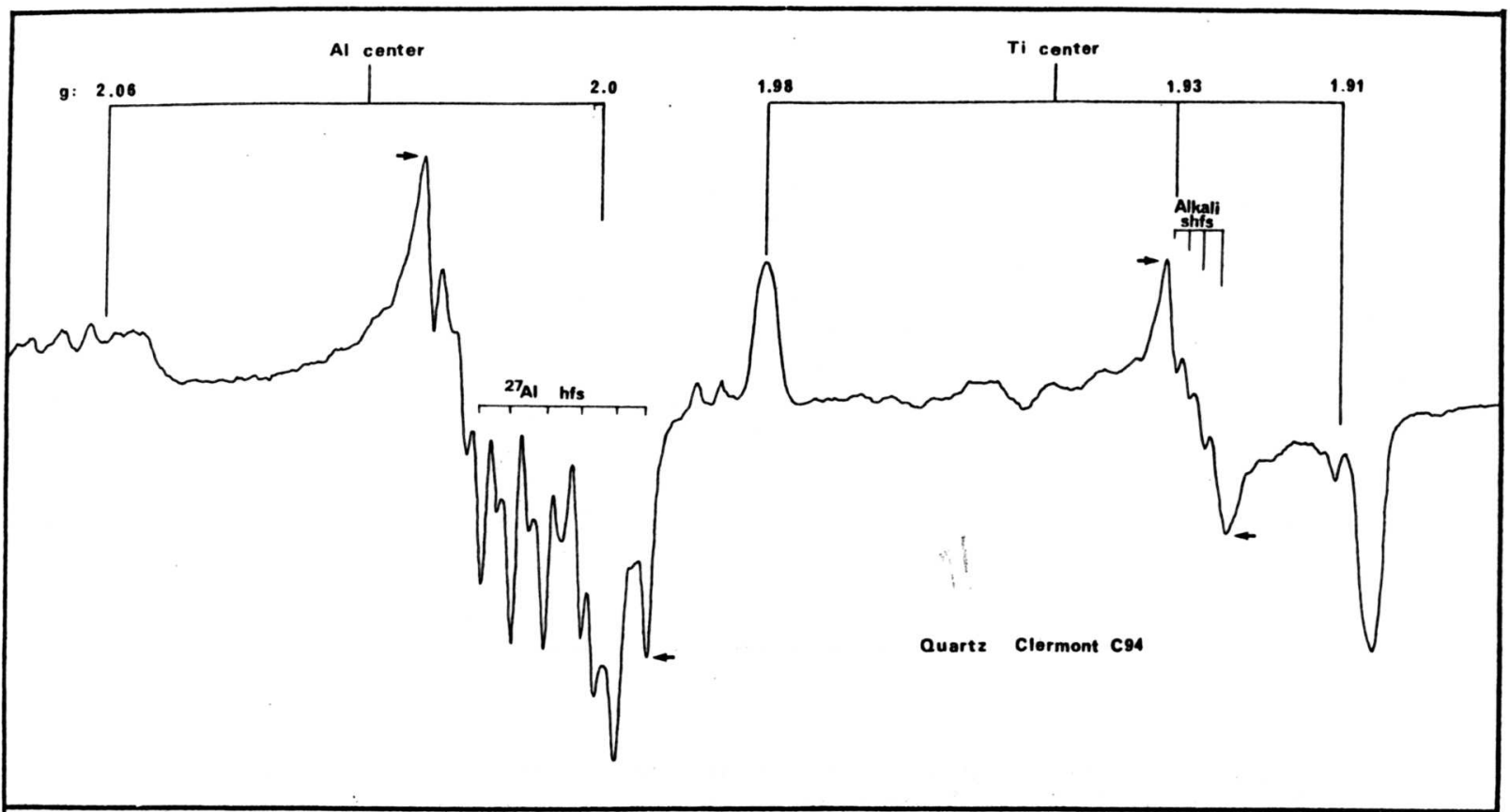

FIG. 2. ESR spectrum of $\mathrm{Al}$ and $\mathrm{Ti}$ centres of quartz from Neschers sediment (C94). ESR cavity temperature of $93 \mathrm{~K}$ is used. The microwave power is $5 \mathrm{~mW}$ for $\mathrm{Al}$ centre and $20 \mathrm{~mW}$ for $\mathrm{Ti}$ centre.

two main components at $g=2.010$ and $g=2.060$. The black arrows in Fig. 2 show how the signal height was measured.

\section{TL SPECTRA}

The natural TL signal (NTL) exhibited three peaks (Fig. 3) which can be characterized by their temperature on the glow curve and also by their colour (Miallier et al., 1990). A minor peak lies around $400 \mathrm{~nm}$ at $220^{\circ} \mathrm{C}$; the main peak is visible in a wide region of the spectrum, at least between 300 and $550 \mathrm{~nm}$, and rises at $320^{\circ} \mathrm{C}$, and a red peak (RTL) around $600-620 \mathrm{~nm}$ rises at $380^{\circ} \mathrm{C}$. After gammairradiation in the laboratory these peaks grow, and others, which probably are not stable at room temperature, appear (Fig 4).

\section{ESR-TL COMPARISON}

\section{Palaeodoses and ages}

As shown in Table 1, the palaeodoses obtained by the ESR method ( $\mathrm{Al}$ and $\mathrm{Ti}$ centres) are poorly consistent with those obtained by TL method (additive technique). For TL, the palaeodose was derived from extrapolation using the growth curve obtained with an annealed and re-irradiated sample ("second growth"), and there is great confidence in the result (Pilleyre et al., 1990).

The ESR palaeodoses were determined by the additive method and obtained by using a saturating exponential fit, because no "second growth" was measured. In TL, from several experiments, we know that growth curves cannot be entirely fit by a saturating exponential fit, and the discrepancy increases as the dose increases. This can explain why, although they nearly merge at low doses, the two ESR ( $\mathrm{Al}$ and $\mathrm{Ti})$ growth curves do not give equal palaeodoses when they are exponentially fit. The Ti signal exhibits a saturating exponential-like growth, slightly above

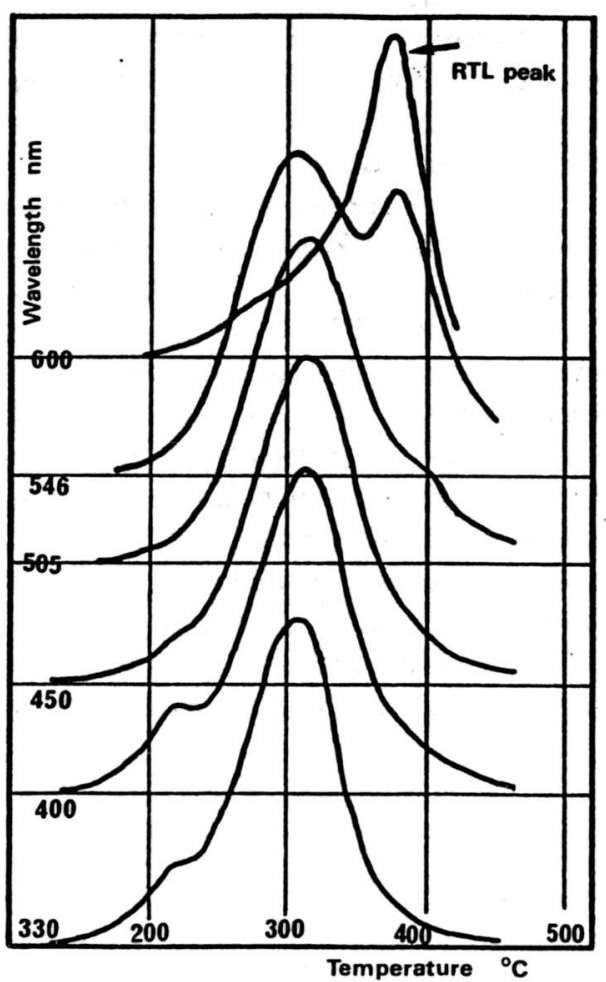

Fig. 3. Natural glow curve of C94 quartz sample (palaeodose about $70 \mathrm{~Gy}$ ) as seen through various narrow band interferential filters. The curves are normalized and the blackbody background was subtracted. Atmosphere: nitrogen; heating rate: $5^{\circ} \mathrm{C} \mathrm{s}^{-1}$. The peak observed here around $600 \mathrm{~nm}$ is typical of the so-called RTL (from Miallier et al., 1990). 


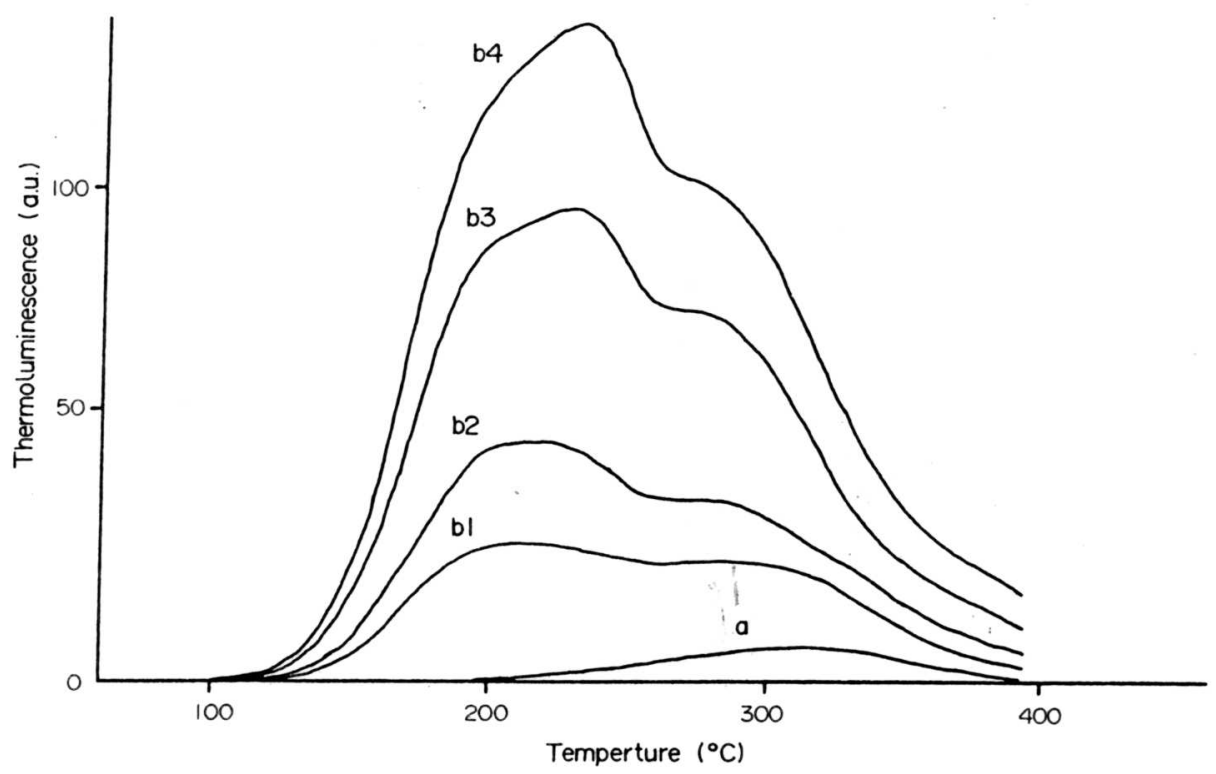

FIG. 4. TL spectra of $\mathrm{C} 94$ quartz sample. Blue filter BG12 Leitz. Heating rate; $5^{\circ} \mathrm{C} \mathrm{s}^{-1}$. Flowing nitrogen. The blackbody background was subtracted and the curves are averaged over ten of them. a: NTL; b: natural + dose; b1: $146 \mathrm{~Gy}$; b2: $274 \mathrm{~Gy}$; b3: $554 \mathrm{~Gy}$; b4: $821 \mathrm{~Gy}$. Two peaks, around 180 and $220^{\circ} \mathrm{C}$ are present on artificially induced TL and not on NTL, because they are not stable at room temperature. The "pre-dose" peak, around $100-110^{\circ} \mathrm{C}$, can also be observed on this sample when it is glowed immediately after irradiation. It cannot be seen here because the curves were recorded several weeks after irradiation.

the red TL growth (Fig. 5). The Al signal is higher than the Ti signal and seems to initiate a second rise above $800 \mathrm{~Gy}$. This should be confirmed by further experiments at higher doses, because this behaviour is very rare in ESR.

The results presented below for C94 sample are similar, qualitatively, to those obtained on other quartz grains extracted from various origins tested in the Clermont laboratory.

Blue TL exhibits a supralinear growth curve at high added doses (at least $4 \mathrm{kGy}$ ), whatever the temperature on the glow curve. At low dose, roughly between NTL, around 70 and $820 \mathrm{~Gy}$, it is almost linear. A saturating exponential-like growth curve is observed when preheating $\left(345^{\circ} \mathrm{C}\right.$ for $\left.10 \mathrm{~s}\right)$ is used (Fig. 5), also followed by a supralinear growth at high doses. RTL exhibits a saturating exponential-like growth at low doses, which has a tendency to become linear at high doses. A second rise, as for BTL, was never observed with RTL, even at very high doses.

It is not intended here to thoroughly discuss the comparisons, because more experimental and theor-

Table 1. Palaeodoses and ages obtained by ESR and TL methods on C94 sample

\begin{tabular}{lcccc}
\hline & \multicolumn{2}{c}{ ESR } & & TL \\
\cline { 2 - 3 } & Al & Ti & & Red peak \\
\hline Palaedoses* (Gy) & $96 \pm 7$ & $80 \pm 7$ & & $70 \pm 5$ \\
Ages $\left(10^{3}\right.$ yr) & $20 \pm 2$ & $17 \pm 2$ & & $13.7 \pm 1.6$ \\
\hline
\end{tabular}

*The paleodose was derived from an exponential fit for ESR and using a "second glow" growth curve for TL. This can explain the discrepancy between different results. Annual doses are not equal because the used grains sizes were not the same for TL and ESR. etical work is needed. Only a few remarks will accompany these preliminary results. Table 1 shows the palaeodoses and ages obtained by ESR and TL methods on C94 samples.

Concerning ESR studies, a first analysis was done on the same sediment. This sample, called TL44 (Yokoyama et al., 1985a), gave exactly the same palaeodose for the Al centre ( $96 \pm 9 \mathrm{~Gy})$, but a little bit higher for the Ti centre $(91 \pm 18 \mathrm{~Gy})$. If we take into account the statistical error, we can conclude that the samples TL 44 and C94 which are extracted from the same sediment are reproducible. These results show a good reliability of the ESR dating method.

For the annual dose, the ${ }^{238} \mathrm{U},{ }^{226} \mathrm{Ra},{ }^{222} \mathrm{Rn},{ }^{228} \mathrm{Ra}$ and ${ }^{40} \mathrm{~K}$ activities of the $\mathrm{C} 94$ sediments have been determined by gamma-ray spectrometry using a high purity germanium detector (GeHP). Cosmic and

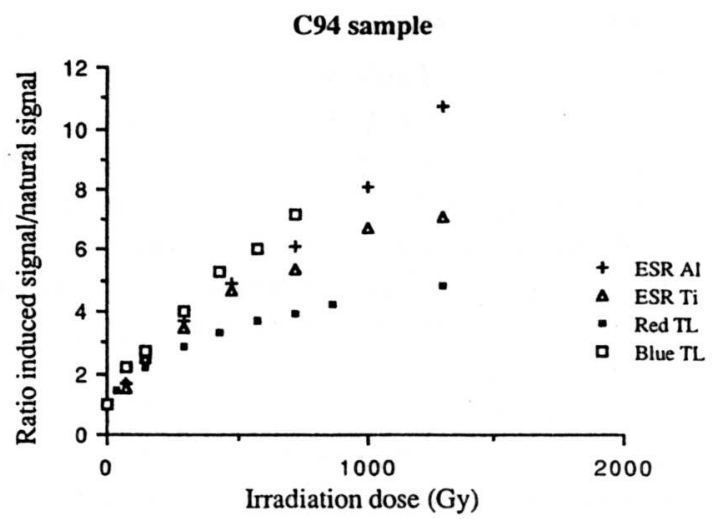

Fig. 5. Growth-curves for blue and red TL peaks and for Al and Ti centres of quartz C94. The curves are traced by the least-squares method. 


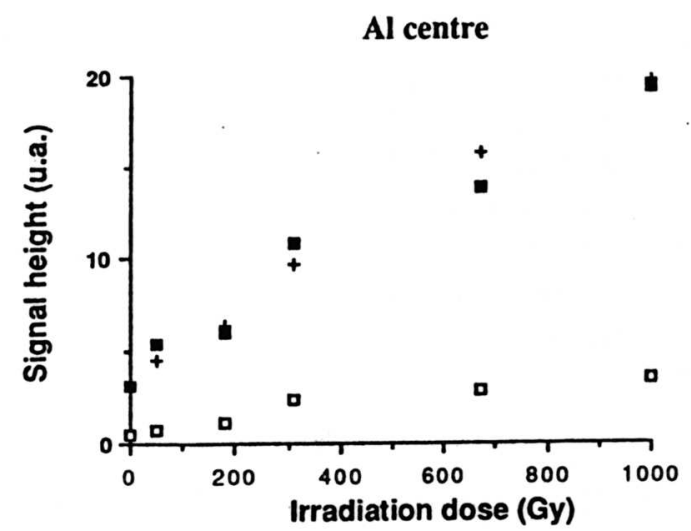

Fig. 6a

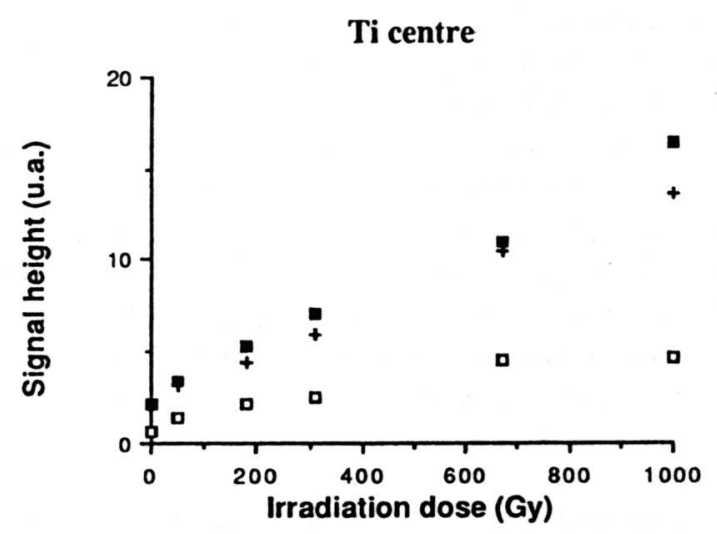

Fig. 6b

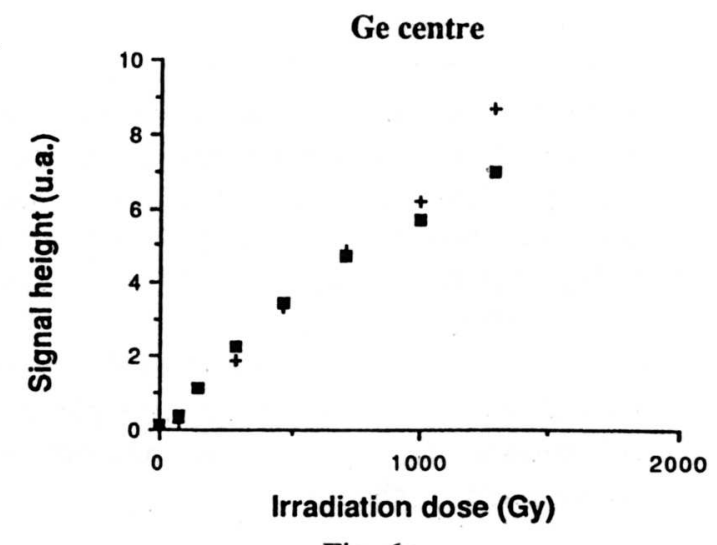

Fig. 6c

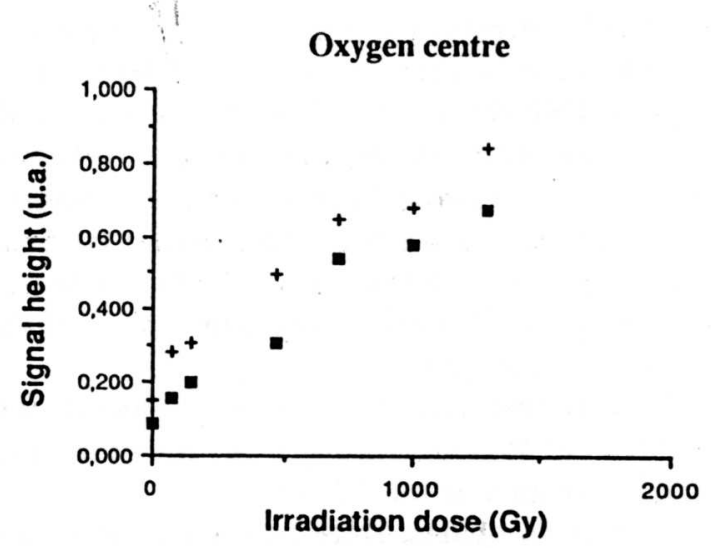

Fig. 6d

Fig. 6. Growth curves for $\mathrm{Al}, \mathrm{Ti}, \mathrm{Ge}$ and $\mathrm{OH}$ centres in $\mathrm{C} 94$ sample. For the four diagrams, crosses correspond to natural samples, black squares represent samples baked at $10^{\circ} \mathrm{C}$ and white squares show growth curves for samples annealed at $180^{\circ} \mathrm{C}$.

internal alpha doses were calculated by Guérin (1983) for the TL44 sample. We used these results for C94 sample.

Recently, Bastin et al. (1990) found a tephra layer dated 10750 BP $\left({ }^{14} \mathrm{C}\right)$ in a core drilled out of peatbogs in the south of the Chaîne des Puys, which they tentatively attributed to the Tartaret volcano (15-22 km north of the peat-bogs). Taking into account an age correction of $\sim 1000-2000$ yr for ${ }^{14} \mathrm{C}$ at this period (Stuiver et al., 1986; Vogel, 1987), we could then get to about 11750-12750, which happens to fall within the error limits of the TL age $(13700 \pm 1600 \mathrm{yr})$.

The growth curves of the $\mathrm{Al}, \mathrm{Ti}$ and $\mathrm{Ge}$ centres are compared (Fig. 6). The growth seems similar. But as we did not observe any Ge signal in the natural samples, it was impossible to use this centre to determine the C94 palaeodose. According to McKeever (1990), the Ge centre would correspond to the blue TL peak at $100^{\circ} \mathrm{C}$ which is not stable, and that can be seen only after recent irradiation. So we can deduce that the Ge centre does not correspond to the red TL peak. On the other hand, we can observe in an ESR sample that the Ge signal is not affected at $110^{\circ} \mathrm{C}$. This contradiction between TL and ESR results is not explained yet. It seems that this question is complex and we do not have enough information to give more details for the moment.

\section{Light effect}

In order to test if sunlight had an effect on the signal height of quartz, two series of the same sample (C94) were prepared. One was exposed to daylight without any precaution before and during preparation. This one was called "light-exposed". The other was entirely protected from daylight ("lightobscured"). Figure 7 shows that there is no significant difference between "unexposed" and "exposed" samples for $\mathrm{Al}$ and $\mathrm{Ti}$ centres. These results are in agreement with TL measurements which indicate that

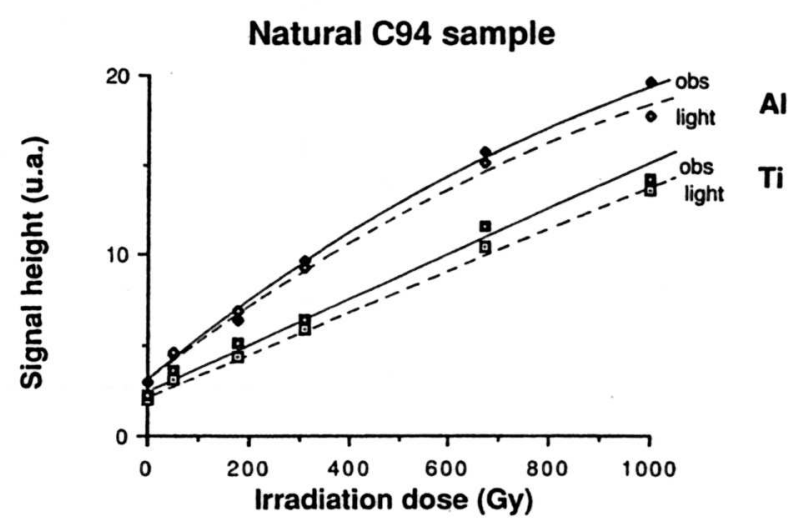

FIG. 7. Comparison between "obscurity" and "light" C94 natural samples for $\mathrm{Al}$ and $\mathrm{Ti}$ centres. obs = light-obscured and light $=$ light-exposed. 
the red TL peak is not sensitive to light exposure (Miallier et al., 1990). The main blue peak decreases with light exposure. As several authors did before, we observed two components in the decay curve, corresponding to at least two components of the peak. The first decay is rapid $(-30 \%$ after $1 \mathrm{~min}$ at $365 \mathrm{~nm} / 226 \mathrm{Wm}^{-2}$ ) and then it becomes exponential ( $-50 \%$ after $100 \mathrm{~min})$.

The pre-dose peak $\left(100-110^{\circ} \mathrm{C}\right)$, not existing in natural TL, grows when the sample is lit, by a well-known phenomenon of phototransfer from deeper traps to shallower traps.

\section{Thermal stability}

The thermal experiments were not performed using the same furnace for TL (in the Clermont laboratory) and ESR (in the Paris laboratory), but the differences in behaviour are large enough not to be entirely due to temperature calibration of the furnaces.

Figure 8 shows that ESR signals disappear after an annealing temperature of $200^{\circ} \mathrm{C}$ while the signal height of TL peak is still about $65 \%$ of the natural sample's height.

The observed ESR centres' behaviour is similar to the behaviour observed in previous experiments (Yokoyama et al., 1985b).

In C94 quartz, three peaks are detected by TL at 220,320 and $380^{\circ} \mathrm{C}$ (Fig. 3). We heated our sample at 252,352 and $406^{\circ} \mathrm{C}$ for $2 \mathrm{~min}$ in order to eliminate peak after peak. After each annealing, we observed our sample by ESR spectroscopy to see if there was an influence on the ESR signal height: after the $252^{\circ} \mathrm{C}$ annealing $\mathrm{Al}, \mathrm{Ti}$ and $\mathrm{Ge}$ centres were destroyed.

This experiment reveals that the ESR centres do not have the same thermal stability as that of the red TL peak, and the main blue TL peak.

\section{CONCLUSION}

These experiments allow us to conclude that we did not find any correspondence between our observed ESR signals and TL peaks. Exception should be outlined for the $100-110^{\circ} \mathrm{C}$ peak, not studied in the present work, for which convincing correlations between TL and ESR were found (McKeever, 1990). The cause of the red TL peak in several natural quartz samples has been investigated from the point of view of impurity elements like europium and samarium content (Hashimoto et al., 1986). These authors noticed a relationship between Eu content and ratios of red TL to total TL intensities.

From an ESR point of view, on a "very young" sample like C94, the sensitivity of the apparatus is important. Signals which can be observed by the TL method are not necessarily detectable by ESR spectroscopy, even more trap centres can be seen by this

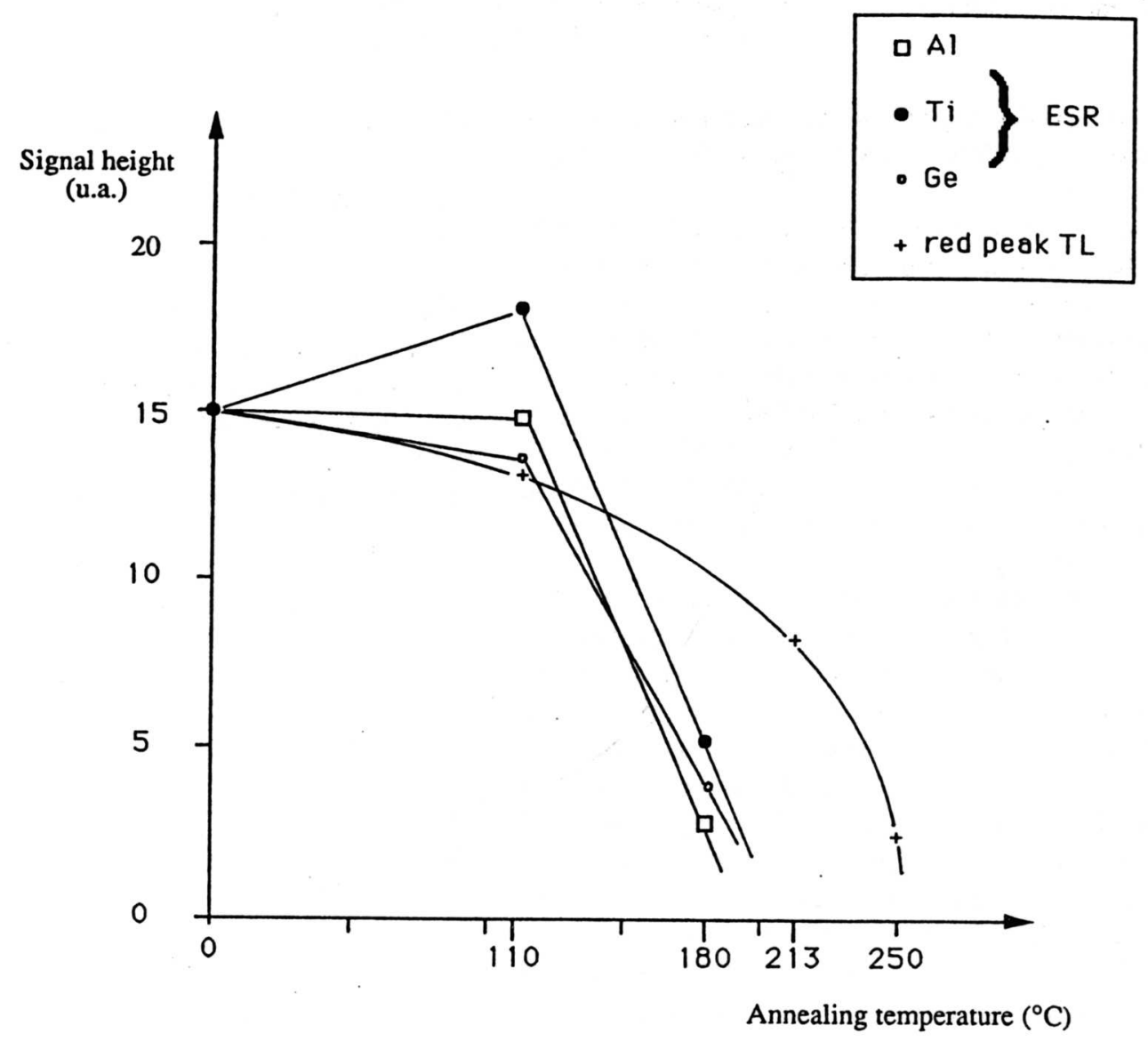

FIG. 8. Isochronal pulse annealing of the ESR centres and red TL peak. The samples have been heated during $16 \mathrm{~h}$ for each annealing temperature. This experiment was done with irradiated ESR samples (1288 Gy) and natural TL samples. 
latter method. There is another possible explanation for why no correspondence between TL peaks and ESR signals was found. It may be that the TL donor corresponds to a double-electron trap which is not possible to detect by the ESR method.

\section{REFERENCES}

Bastin B., Gewelt M. and Juvigné E. (1990) A propos de l'âge et de l'origine des tephras tardiglaciaires T4 et T5 de Godivelle-Nord (Massif Central, France). Ann. Soc. Geol. Belg. 113, (in press).

Fukuchi T. (1988) Applicability of ESR dating using multiple centres to fault movement. The case of Itoigawa-Shizuoka tectonic line, a major fault in Japan. Quat. Sci. Rev. 7, 509-514.

Griscom D. L. (1978) Defects and impurities in alpha-quartz and fused silica. In The physics of $\mathrm{SiO}_{2}$ and its interfaces (Edited by Pantelides, S. T.), pp. 232-252. Proc. Int. Topical Conf., Yorktown, New York.

Griscom D. L. and Friebele E. J. (1981) Fundamental defect centres in glass: ${ }^{29} \mathrm{Si}$ hyperfine structure of the nonbridging oxygen hole center and the peroxy radical in a-SiO ${ }_{2}$. Phys. Rev. B 24, 4896-4898.

Guérin G. (1983) La thermoluminescence des plagioclases, méthode de datation du volcanisme: applications au domaine volcanique français: chaîne de Puys, MontDore et Cézallier, Bas Vivarais. Thèse Doctorat d'Etat Paris, Université P. et M. Curie.

Hashimoto T., Hayashi Y., Koyanagi A., Yokosaka K. and Kimura K. (1986) Red and blue colouration of thermoluminescence from natural quartz sands. Nucl. Tracks Radiat. Meas. 11, 229-235.

McKeever S. W. S. (1990) Mechanisms of thermoluminescence production: some problems and a few answers. Sixth Int. Spec. Seminar Thermoluminesc. Electron Spin Resonance Dating, Clermont-Ferrand, France, 2-6 July. Nucl. Tracks Radiat. Meas. 18, 5-12.

McMorris D. W. (1970) ESR detection of fossil alpha damage in quartz. Nature 226, 146-148.
McMorris D. W. (1971) Impurity color centers in quartz and trapped electron dating: electron spin resonance, thermoluminescence studies. J. Geophys. Res. 76, 7875-7887.

Miallier D., Faïn J., Montret M., Pilleyre T., Sanzelle S. and Soumana S. (1990) Properties of the red TL peak quartz relevant to thermoluminescence dating. $\mathrm{Nucl}$. Tracks Radiat. Meas. 18, 89-94.

Pilleyre T., Montret M., Faïn J., Miallier D. and Sanzelle S. (1990) Attempts at dating ancient volcanoes using the red TL of quartz. Quat. Sci. Rev. (in press).

Sanzelle S., Faïn J. and Miallier D. (1984) Datation par thermoluminescence d'une coulée volcanique à Neschers (Puy de Dôme). Phys. Corpusc. Clermont-Ferrand (PCCF), inner report.

Shimokawa K., Imai N. and Hirota M. (1984) Dating of a volcanic rock by ESR. Isotope Geosci. 2, 365-373.

Stapelbroek M. and Griscom D. L. (1978) Oxygenassociated trapped hole centres in high purity fused silica. In The physics of $\mathrm{SiO}_{2}$ and its interfaces (Edited by Pantelides S. T.), pp. 263-267. Proc. Int. Topical Conf., Yorktown, New York.

Stuiver M., Krome B., Becker B. and Ferguson C. W. (1986) Radiocarbon age calibration back to $13,300 \mathrm{yr}$ BP and the ${ }^{14} \mathrm{C}$ age matching of the German oak and U.S. Bristlecone pine chronologies. Radiocarbon 28 , 969-979.

Vogel J. C. (1987) Calibration of radiocarbon dates beyond $10,000 \mathrm{BP}$. In chronologies in the Near East (Edited by Avrenche O., Evin J. and Hours F.). BAR International series.

Weil J. A. (1984) A review of electron spin spectroscopy and its application to the study of paramagnetic defects in crystalline quartz. Phys. Chem. Miner. 10, 149-165.

Yokoyama Y., Falguères C. and Quaegebeur J. P. (1985a) ESR dating of sediment baked by lava-flows: comparison of palaedoses for $\mathrm{Al}$ and $\mathrm{Ti}$ centres. In ESR Dating and Dosimetry, pp. 197-204. Ionics, Tokyo.

Yokoyama Y., Falguères C. and Quaegebeur J. P. (1985b) ESR dating of quartz from quaternary sediments: first attempt. Nucl. Tracks 10, 921-928. 